\title{
Modern challenges in the education of young surgeons: the two sides of the coin-hours restriction: the resident's point of view
}

\author{
Bárbara Fernandes Nadaleto, Fernando Augusto Mardiros Herbella \\ Department of Surgery, Federal University of São Paulo, São Paulo, Brazil \\ Contributions: (I) Conception and design: None; (II) Administrative support: FAM Herbella; (III) Provision of study materials or patients: None; \\ (IV) Collection and assembly of data: None; (V) Data analysis and interpretation: BF Nadaleto; (VI) Manuscript writing: Both authors; (VII) Final \\ approval of manuscript: Both authors. \\ Correspondence to: Bárbara Fernandes Nadaleto, MD. Chief Resident Gastrointestinal Surgery, Department of Surgery, Federal University of São \\ Paulo, Dr. Diogo de Faria St., n. 1291, ap. 9, São Paulo, Brazil. Email: barbara.nadaleto@unifesp.br.
}

\begin{abstract}
There is a concern about extensive duty hours all over the world and the consequences of work overload and sleep deprivation in residents' well-being, education, and patient safety. Some countries have limited duty periods during residency in order to avoid medical errors caused by fatigue and to improve residents' quality of life and learning. Surgical training is, however, an additional concern since experience in the operating room is difficult to be replaced by other study methods. Observational and interventional studies show that restless residents make more prescriptions and diagnostic errors, take more time to complete surgical tasks and have an impaired accuracy. The main concern of residents regarding hours restriction is the possibility of having fewer opportunities to perform surgical procedures. Interruptions in the continuity of care is also an issue presented in this topic. The heterogeneity of methodology among studies regarding this subject in the literature makes results conflicting and hard to assess. Burnout syndrome is a prevalent condition among doctors. Its incidence in young surgeons is worrisome and can jeopardize learning. Duty period restrictions can improve residents' well-being and have no negative effect on patient safety and quality of care. Cultural changes must be done in order to stop romanticizing overwork in medical career and lessen its consequences.
\end{abstract}

Keywords: Residency; surgery; hour restriction; patient safety; residents' well-being

Received: 04 May 2021; Accepted: 29 June 2021; Published: 30 September 2021.

doi: 10.21037/asj-21-24

View this article at: https://dx.doi.org/10.21037/asj-21-24

\section{Introduction}

Residency is known to be a rough although fundamental step in every physician career. There is concern about extensive duty hours all over the world and the consequences on residents' well-being, education and patient safety. This topic has been under debate since the 1970s $(1,2)$ but changes in regulation only took place after the death of a young medical student under the care of overworked residents in a New York teaching hospital in 1984 (3). Also, the physicians' quality of life was a matter that started to be debated in that decade (4). Nowadays, some countries have limited residents' duty periods, restricted maximum shift lengths, and established a minimum time off between work days (5) in order to avoid medical errors caused by fatigue and sleep deprivation and improve their well-being.

Surgical training is, however, an additional concern since experience in the operating room is difficult to be replaced by other study methods. Practical skills, such as operative technique and non-technical skills like behavior, communication, professionalism, and decision making, are fundamental to ensure a successful independent career after graduation (6). Different from clinical specialties, surgical trainees need hands-on experiences to consolidate what was learned in the books, which is hard to do outside the hospital even with simulation. Lack of familiarity with the patient and disruption of continuity of care are also factors 
that worry mentors in surgical residencies regarding hours restriction implementation (7).

\section{Hours restriction}

Many countries have established guidelines with restrictions for duty periods in residency programs in the past three decades. For example, in Europe there is a limit of 48 work hours per week (hr/wk), while in Brazil the limit is 60 and $80 \mathrm{hr} / \mathrm{wk}$ in the United States of America (USA) $(5,8)$. In Canada, there is a maximum limit of 16 work hours in a row, which is also the limit for junior residents in the USA (5). A 24-hour shift is the limit for Brazilian residents and USA's intermediate and senior residents $(5,8)$. In Europe, residents in a stressful position-like in an emergency room-can work a maximum of 8 hours per day (5). Most countries establish a 24-hour period free of work in a week and 30 days off in a year $(5,8)$. However, many institutions are flexible, not following strictly these rules. This flexibility aims to avoid residents leaving the patient care in critical times, like during an operation, or miss opportunities to perform invasive procedures $(7,9,10)$.

\section{Pros}

The idea behind hours restriction is that tired sleepless residents make more mistakes. Some prospective interventional studies with ward and intensive care unit (ICU) residents and interns in academic hospitals present lower $(22-33 \%)$ medical error in groups with limited duty hours $(11,12)$. Medication errors were more frequent and diagnostic errors were almost twice as common in traditional schedules (11). Observational studies also show lower error rates and no negative effect of reduced work hours on patient safety and quality of care $(13,14)$.

Regarding surgical training, stress and sleep deprivation seems to negatively affect cognitive and motor abilities. Several studies with laparoscopic surgical trainees reveal that residents who performed the tasks after a night on call had a significantly greater number of errors, lengthened time to complete tasks and impaired accuracy compared to those with a full night sleep (15-19).

Beside patient safety, another goal to implement hours restriction policy is to improve residents well-being. Many studies report positive effects of this measure on residents quality of life, time for rest, research participation, health and time with family and friends $(7,10)$. Residents in sleep deprivation often relate disinterest, difficulty in learning, loss of empathy and concern for the patients, less patience with colleagues and students and less interactions with staff $(20,21)$. The incidence of burnout syndrome and other mental health conditions is higher among doctors in this situation, leading to dissatisfaction with career and life (22).

\section{Cons}

Data about this topic is still contradictory. Many studies have heterogeneous methods of assessment of quality of patient care and resident welfare, resulting in different outcomes, that makes it hard to draw significant conclusions $(22,23)$.

A large prospective trial conducted by Bilimoria et al. in the USA in 2014 (FIRST-trial) compared outcomes in institutions that strictly followed the duty hours restriction with more flexible ones that allowed longer work hours in a day with shorter time off between the shifts. Over 130,000 patients and 4,000 general surgery residents were enrolled in the study. Patient mortality and number of complications seem to be similar between institutions with strict and flexible duty hours (10). Systematic literature reviews also present no advantage of hours restriction policy regarding patient care, mortality, and postoperative complications $(22,23)$. Some retrospective studies reported a small but significant decrease in the number of procedures performed by residents after hours restriction implementation (24).

The main concern pointed out in several studies is the continuity of patient care, which was subjectively reported to be impaired with hour restriction programs $(7,9,10,25)$. They also report to miss more opportunities to learn and perform procedures when they strictly follow the hours cap (12) resulting in a potential impairment on learning (23). Residents in more flexible institutions complained less about operative volume, autonomy, professionalism, team bonds and time to teach younger students $(9,10)$. Some studies point that paradoxically residents felt an increase in the amount of work to do after the restriction (9) and that it did not improve the sleep deficit (21). The satisfaction about overall education quality, career choice and overall well-being were also reported to be similar in both groups $(10,23)$.

\section{Discussion}

Residency is a life period when the foundations of a doctor's career are built, not only in theoretical and practical knowledge, but also in decision making, teamwork and professionalism. Dealing with emotions and expectations 
and balancing workload, social life and personal health is a challenge for most physicians. Burnout syndrome in doctors is a very prevalent condition that can cause anxiety, depression, alcohol and drug abuse, sleep disorders, social and family distancing that can lead to professional and personal frustrations, sometimes ending up with suicide (26). Also, metabolic disorders can be triggered by chronic sleep deprivation such as diabetes, impaired immune function, gut microbiota dysregulation, obesity, and hypertension (27). This vicious cycle often starts with interns and residents learning to work to exhaustion in teaching hospitals, making this discussion fundamental within institutions. Hours restriction policies—as well as the availability of tutors and a support network-are necessary to break this cycle. Flexibility on applying the rules may be one strategy to avoid unwanted interruptions in patient care and residents' learning process.

Most papers in this subject fail to prove a real effect of fatigue on surgical performance of attending surgeons $(22,28)$. This may show that residents in training may be the most affected ones with insufficient sleep hours, as observed in interventional studies (15-17,19). Apparently, experienced surgeons can adapt to chronic sleeplessness $(19,29)$ resulting in less risk for their patients, but not for themselves since the metabolic and psychiatric consequences remain $(26,27)$.

If other stressful professions that deal with lives-i.e., aviation and police force-have rules on duty hours, why should medicine not have? A cultural shift must be done to stop romanticizing overworking, not only during residency but in medical career as well. There is no doubt that time in the hospital is essential in the formation of a physician, but there must be limits established to contain the consequences of a workaholic profession.

\section{Acknowledgments}

Funding: None.

\section{Footnote}

Provenance and Peer Review: This article was commissioned by the editorial office, AME Surgical fournal for the series "Modern Challenges in the Education of Young Surgeons: the Two Sides of the Coin". The article has undergone external peer review.

Conflicts of Interest: Both authors have completed the ICMJE uniform disclosure form (available at https://asj.amegroups. com/article/view/10.21037/asj-21-24/coif). The series "Modern Challenges in the Education of Young Surgeons: the Two Sides of the Coin" was commissioned by the editorial office without any funding or sponsorship. FAMH served as an unpaid Guest Editor of the series and serves as an unpaid editorial board member of AME Surgical fournal from February 2021 to January 2023. The authors have no other conflicts of interest to declare.

Ethical Statement: The authors are accountable for all aspects of the work in ensuring that questions related to the accuracy or integrity of any part of the work are appropriately investigated and resolved.

Open Access Statement: This is an Open Access article distributed in accordance with the Creative Commons Attribution-NonCommercial-NoDerivs 4.0 International License (CC BY-NC-ND 4.0), which permits the noncommercial replication and distribution of the article with the strict proviso that no changes or edits are made and the original work is properly cited (including links to both the formal publication through the relevant DOI and the license). See: https://creativecommons.org/licenses/by-nc-nd/4.0/.

\section{References}

1. 1. Friedman RC, Bigger JT, Kornfeld DS. The intern and sleep loss. N Engl J Med 1971;285:201-3.

2. Cousins N. Internship: preparation or hazing ? JAMA 1981;245:377.

3. Asch DA, Parker RM. The Libby Zion case. One step forward or two steps backward? N Engl J Med 1988;318:771-5.

4. Parker JB. The effects of fatigue on physician performance-an underestimated cause of physician impairment and increased patient risk. Can J Anaesth 1987;34:489-95.

5. Temple J. Resident duty hours around the globe: where are we now?. BMC Med Educ 2014;14 Suppl 1:S8.

6. Sanfey H. Assessment of surgical training. Surgeon 2014;12:350-6.

7. Barden CB, Specht MC, McCarter MD, et al. Effects of limited work hours on surgical training. J Am Coll Surg 2002;195:531-8.

8. Dispõe sobre as atividades do médico residente e dá outras providências. Available online: https://www2.camara. leg.br/legin/fed/lei/1980-1987/lei-6932-7-julho-1981357276-normaatualizada-pl.html

9. Lachance S, Latulippe JF, Valiquette L, et al. Perceived 
effects of the 16-hour workday restriction on surgical specialties: Quebec's experience. J Surg Educ 2014;71:707-15.

10. Bilimoria KY, Chung JW, Hedges LV, et al. National Cluster-Randomized Trial of Duty-Hour Flexibility in Surgical Training. N Engl J Med 2016;374:713-27.

11. Landrigan CP, Rothschild JM, Cronin JW, et al. Effect of reducing interns' work hours on serious medical errors in intensive care units. N Engl J Med 2004;351:1838-48.

12. Cappuccio FP, Bakewell A, Taggart FM, et al. Implementing a $48 \mathrm{~h}$ EWTD-compliant rota for junior doctors in the UK does not compromise patients' safety: assessor-blind pilot comparison. QJM 2009;102:271-82.

13. Collum J, Harrop J, Stokes M, et al. Patient safety and quality of care continue to improve in NHS North West following early implementation of the European Working Time Directive. QJM 2010;103:929-40.

14. Barger LK, Ayas NT, Cade BE, et al. Impact of extendedduration shifts on medical errors, adverse events, and attentional failures. PLoS Med 2006;3:e487.

15. Grantcharov TP, Bardram L, Funch-Jensen P, et al. Laparoscopic performance after one night on call in a surgical department: prospective study. BMJ 2001;323:1222-3.

16. Eastridge BJ, Hamilton EC, O'Keefe GE, et al. Effect of sleep deprivation on the performance of simulated laparoscopic surgical skill. Am J Surg 2003;186:169-74.

17. Taffinder NJ, McManus IC, Gul Y, et al. Effect of sleep deprivation on surgeons' dexterity on laparoscopy simulator. Lancet 1998;352:1191.

18. Brandenberger J, Kahol K, Feinstein AJ, et al. Effects of duty hours and time of day on surgery resident proficiency. Am J Surg 2010;200:814-8; discussion 818-9.

19. Tsafrir Z, Korianski J, Almog B, et al. Effects of Fatigue on Residents' Performance in Laparoscopy. J Am Coll Surg

doi: $10.21037 /$ asj-21-24

Cite this article as: Nadaleto BF, Herbella FAM. Modern challenges in the education of young surgeons: the two sides of the coin-hours restriction: the resident's point of view. AME Surg J 2021;1:17. 2015;221:564-70.e3.

20. Papp KK, Stoller EP, Sage P, et al. The effects of sleep loss and fatigue on resident-physicians: a multi-institutional, mixed-method study. Acad Med 2004;79:394-406.

21. Baldwin DC Jr, Daugherty SR. Sleep deprivation and fatigue in residency training: results of a national survey of first- and second-year residents. Sleep 2004;27:217-23.

22. Gates M, Wingert A, Featherstone R, et al. Impact of fatigue and insufficient sleep on physician and patient outcomes: a systematic review. BMJ Open 2018;8:e21967.

23. Bolster L, Rourke L. The Effect of Restricting Residents' Duty Hours on Patient Safety, Resident Well-Being, and Resident Education: An Updated Systematic Review. J Grad Med Educ 2015;7:349-63.

24. Kairys JC, McGuire K, Crawford AG, et al. Cumulative operative experience is decreasing during general surgery residency: a worrisome trend for surgical trainees? J Am Coll Surg 2008;206:804-11; discussion 811-3.

25. Coverdill JE, Carbonell AM, Cogbill TH, et al. Professional values, value conflicts, and assessments of the duty-hour restrictions after six years: a multi-institutional study of surgical faculty and residents. Am J Surg 2011;201:16-23.

26. Kumar S. Burnout and Doctors: Prevalence, Prevention and Intervention. Healthcare (Basel) 2016;4:37.

27. Potter GD, Skene DJ, Arendt J, et al. Circadian Rhythm and Sleep Disruption: Causes, Metabolic Consequences, and Countermeasures. Endocr Rev 2016;37:584-608.

28. Sugden C, Athanasiou T, Darzi A. What are the effects of sleep deprivation and fatigue in surgical practice? Semin Thorac Cardiovasc Surg 2012;24:166-75.

29. Olasky J, Chellali A, Sankaranarayanan G, et al. Effects of sleep hours and fatigue on performance in laparoscopic surgery simulators. Surg Endosc 2014;28:2564-8. 